\title{
Long-term regulation of hexose transport by insulin in cultured mouse (3T3) adipocytes
}

\author{
J.P.M.van Putten, Tj. Wieringa and H. M.J.Krans \\ Laboratory for Diabetes Research, Department of Endocrinology and Metabolic Diseases, University Hospital, Leiden, The Netherlands
}

\begin{abstract}
Summary. Observations in vivo suggest that insulin acts as a long-term regulator of hexose uptake in fat cells. In the present study, we examined the long-term effect of insulin on hexose uptake in vitro. Exposure of fully differentiated mouse 3T3- $\mathrm{L}_{1}$ adipocytes to insulin induced a time-, concentration-, and protein synthesis-dependent increase in basal 2-deoxyglucose uptake (up to 40\%) and a decrease in the 'acute' insulin response. The decrease in insulin effect was due to post-receptor alterations, since insulin binding was not substantially altered. The increase in basal 2-deoxyglucose uptake was due to an increase in the apparent $\mathrm{V}_{\max }$ of the transport system rather than to the observed increase $(30 \%)$ in hexokinase activity, since the concentration of non-phosphorylated 2-deo-
\end{abstract}

xyglucose inside the cell was far below the extracellular concentration. The increase in apparent $V_{\max }$ was most likely due to a protein synthesis-dependent increase in de novo synthesis of hexose transporters. Glucose was not essential for the effect. The mechanism responsible for the loss in insulin response remains to be solved. It can be concluded that insulin has the ability to act as a long-term regulator of hexose uptake in fat cells in vitro.

Key words: Hexose uptake, insulin response, $3 \mathrm{~T}_{3}-\mathrm{L}_{1}$ adipocytes, cycloheximide, hexose transport kinetics, 2-deoxyglucose.
Several observations in vivo suggest a role of insulin in the long-term regulation of insulin-sensitive hexose uptake in fat cells. In insulin-dependent diabetes mellitus and in streptozotocin-induced diabetes in animals, the hexose uptake by fat cells is decreased [1-6]. Hypoinsulinaemia, induced by fasting, is also accompanied by a low rate of basal hexose uptake [7]. In rats on a high carbohydrate diet, which is accompanied by high plasma insulin values, hexose uptake is increased [8-10], and in experiments in which rats were made hypo- and hyperinsulinaemic, the rate of glucose uptake by the fat cells correlates well with the plasma insulin level [11]. In vitro, a correlation between insulin concentration and hexose uptake has been difficult to establish. In isolated fat cells and in adipose tissue explants, no long-term insulin effects on hexose uptake have been found [12-14], but this could be due to limitations of the methods employed. Isolated fat cells are viable only for several hours, while incubation of explants in culture medium for $17 \mathrm{~h}$ induces a 2.5 -fold increase in hexose uptake, even in the absence of insulin [13]. Furthermore, mechanical agitation and the use of digesting enzymes in the fat cell isolation procedure are known to affect hexose uptake [15-17]. The present availability of pre-adi- pocyte cell lines, like the mouse $3 \mathrm{~T} 3-\mathrm{L}_{1}$ pre-adipocyte cell line $[18,19]$, offers the opportunity to study the role of insulin in the regulation of hexose uptake in cultured fat cells.

\section{Materials and methods}

\section{Cell culture}

3T3- $\mathrm{L}_{1}$ pre-adipocytes (Flow Laboratories, Irvine, Ayrshire, UK) were inoculated at a density of $3 \times 10^{3}$ cells $/ \mathrm{cm}^{2}$ and grown to confluence in Dulbecco's Modified Eagle's medium supplemented with glutamine $(2 \mathrm{mmol} / \mathrm{l})$, fetal calf serum $(10 \%)$ and antibiotics (standard medium). Cells were kept at $37^{\circ} \mathrm{C}$ in a humidified atmosphere of $7.5 \%$ $\mathrm{CO}_{2}$ in air, and were fed every other day. Two days post-confluence, adipose conversion was enhanced according to the method of Rubin et al. [20] as modified by Reed and Lane [21]. The cells were cultured in standard medium in the presence of dexamethasone $(0.25 \mu \mathrm{mol} / \mathrm{l})$, 3 -isobutyl-1-methylxanthine $(0.5 \mathrm{mmol} / \mathrm{l})$ and insulin $(1660 \mathrm{nmol} / \mathrm{l})$ for 2 days, and in the presence of insulin alone for 6 days. The cells were then maintained in the absence of insulin for at least 3 additional days. By this procedure, more than $80 \%$ of the cells expressed the adipocyte phenotype. In the experiments, fully differentiated cells were cultured in the presence and absence of insulin. After various periods of time hexose uptake and insulin effectiveness were determined. 


\section{Deactivation procedure}

Before determination of insulin binding and insulin-sensitive hexose uptake, the cells were subjected to a protocol to remove all the cellbound insulin and to deactivate the hexose transport system ('deactivation procedure'). The protocol was as follows: the cells were washed rapidly four times with $2 \mathrm{ml}$ Dulbecco's phosphate buffered saline (PBS), pH 7.4. Standard medium ( $2 \mathrm{ml}$, adjusted to $\mathrm{pH} 7.0$ ) was added and the cells were incubated at $37^{\circ} \mathrm{C}$ for $30 \mathrm{~min}$. The medium was poured off and the cells were washed three times with $2 \mathrm{ml}$ PBS. This procedure was repeated three times. The deactivation procedure was effective in removing $>85 \%$ of the cell-bound insulin. After $1 \mathrm{~h}$ of incubation $\left(37^{\circ} \mathrm{C}\right)$ of the cells with $20 \mathrm{pmol} / 1^{125} \mathrm{I}$-insulin, $12.8 \pm$ $1.0 \%$ of the insulin was bound, whereas after the deactivation procedure insulin binding was $1.8 \pm 0.4 \%$ (mean $\pm \mathrm{SD}, n=3)$. Deactivation of the insulin-stimulated hexose transport system was almost complete also. Exposure of the cells to $1 \mu \mathrm{mol} / 1$ insulin for $30 \mathrm{~min}$ stimulated the basal 2-deoxyglucose uptake from $2.96 \pm 0.26$ to $8.73 \pm$ $0.06 \mathrm{nmol} / 10 \mathrm{~min}$ per well (mean $\pm \mathrm{SD}, n=3$ ). After the deactivation procedure, the 2-deoxyglucose uptake was reduced to $3.33 \pm$ $0.23 \mathrm{nmol} / 10 \mathrm{~min}$ per well, and the deactivated cells showed the same insulin sensitivity and responsiveness as untreated cells. To avoid possible non-specific effects of the deactivation procedure, cells exposed to insulin for $30 \mathrm{~min}$ and subjected to the deactivation procedure, were taken as control cells in all the experiments.

\section{Insulin binding}

Fat cells ( $60 \mathrm{~mm}$ wells) were incubated with $20 \mathrm{pmol} / 1$ mono- $\mathrm{A}^{14}{ }_{-}^{125} \mathrm{I}$ insulin $(360 \mathrm{Ci} / \mathrm{mol})$ in $1.5 \mathrm{ml} \mathrm{Krebs-Ringer} \mathrm{Tris-HCl}$ buffer containing $2 \%$ serum albumin (Tris-buffer), $\mathrm{pH} 7.4$, at $22^{\circ} \mathrm{C}$. Bacitracin $(1.5 \mathrm{mmol} / \mathrm{l})$ was added to inhibited extracellular insulin degradation. The wells were shaken ( 75 oscillations $/ \mathrm{min}$ ) at $22^{\circ} \mathrm{C}$. After $3 \mathrm{~h}$, the cells were rinsed rapidly four times with $2 \mathrm{ml}$ ice-cold PBS, scraped off the dishes and treated with $1 \mathrm{ml}$ of $0.1 \mathrm{~mol} / 1 \mathrm{NaOH}$. Aliquots $(0.1 \mathrm{ml})$ were taken for protein determination [22] and ${ }^{125} \mathrm{I}$ was counted. Non-specific binding was defined as the amount of ${ }^{125} \mathrm{I}$ bound in the presence of an excess of unlabelled insulin $(1000 \mathrm{nmol} / \mathrm{l})$. Cell number was counted in a cell-counting chamber (Tamson, Zoetermeer, The Netherlands) and was constant throughout the experiments $\left(5 \times 10^{5}\right.$ cells $/ 30 \mathrm{~mm}$ well $; 2 \times 10^{6}$ cells $/ 60 \mathrm{~mm}$ well $)$.

\section{2-Deoxyglucose uptake}

Hexose uptake was measured using 2-deoxyglucose. Deactivated fat cells $(30 \mathrm{~mm}$ wells) were incubated in $0.75 \mathrm{ml}$ Tris-buffer $(\mathrm{pH} \mathrm{7.4)} \mathrm{at}$ $37^{\circ} \mathrm{C}$ in the presence and absence of insulin. After $30 \mathrm{~min}, 2$-deoxy-D$\left(1-{ }^{14} \mathrm{C}\right)$ glucose $(0.1 \mathrm{mmol} / 1,710 \mathrm{cpm} / \mathrm{nmol})$ was added, and uptake was followed for $2-10 \mathrm{~min}$. Uptake was stopped by rinsing the cells four times with $1 \mathrm{ml}$ ice-cold PBS. Cells were prepared as for insulin binding, except that ${ }^{14} \mathrm{C}$ was counted in a liquid scintillation counter (Packard Instruments, Grovers Down, Illinois, USA). The nature of the labelled substances present in the cell was determined by column chromatography, as described previously for rat adipocytes [23]. The intracellular concentration of 2-deoxyglucose was calculated after determination of the intracellular waterspace, using the double-labelling technique described by Gliemann et al. [24]. Hexokinase activity was estimated by determination of the rate of phosphorylation of 0.1 $\mathrm{mmol} / 1$ 2-deoxyglucose by cellular homogenates in Tris-buffer, containing ATP $(10 \mathrm{mmol} / 1)$, and $\mathrm{MgCl}_{2}(10 \mathrm{mmol} / \mathrm{l})$ at $37^{\circ} \mathrm{C}$.

\section{Materials}

All culture requisites were purchased from Gibco, Grand Island, New York, except for the culture wells (Greiner, Nürtingen, FRG). Demineralized bovine serum albumin was from Organon, Oss, The Netherlands. 2-deoxy-D-(1-14C)-glucose was obtained from New England Nuclear, Boston, Massachusetts, USA. 3-O-methyl- $\left({ }^{3} \mathrm{H}\right)$-glucose and $\left(\mathrm{U}-{ }^{14} \mathrm{C}\right)$-sucrose were from Amersham International, Buck- inghamshire, UK. Mono- $\mathrm{A}^{14}{ }^{125}$ I-insulin (human and porcine) were generously provided by Eli Lilly Nederland, The Netherlands. Native insulin was from Novo, Copenhagen, Denmark. Dexamethasone and bacitracin were obtained from Sigma, St. Louis, Missouri, USA. Cycloheximide from Serva, Heidelberg, FRG and methylxanthine from Aldrich Chemicals, Milwaukee, Wisconsin, USA.

\section{Data analysis}

Statistical analysis of the data was performed by Student's t-test for paired comparison.

\section{Results}

The long-term effect of insulin on the hexose uptake was examined by culturing the $3 T 3$ fat cells in the presence of insulin $(1000 \mathrm{nmol} / \mathrm{l})$ for $24 \mathrm{~h}$ and for $30 \mathrm{~min}$ (control cells). The cells were then subjected to the deactivation procedure and 2-deoxyglucose uptake was determined (Fig. 1). Prolonged exposure of the cells to insulin increased the basal 2-deoxyglucose uptake by up to $50 \%$ compared with control cells $(n=6, p<0.001)$. By contrast, long-term insulin treatment decreased the acute stimulatory effect of insulin on the uptake. Insulin sensitivity decreased approximately fivefold $\left(E D_{50}\right.$ : $3.10 \pm 0.26$ versus $0.56 \pm 0.15 \mathrm{nmol} / \mathrm{l}$; mean $\pm \mathrm{SD}, n=5$, $p<0.005$ ), whereas maximal insulin-stimulated 2-deoxyglucose uptake (insulin responsiveness) was decreased by approximately $15 \%(n=6, p<0.05) .{ }^{125} \mathrm{I}$-insulin binding $(20 \mathrm{pmol} / 1)$ was not affected by long-term insulin treatment $(9.8 \pm 0.5 \%$ and $11.0 \pm 0.8 \%$ bound per well in insulin-treated $(24 \mathrm{~h})$ and control cells, respectively, mean $\pm \mathrm{SD}, n=6, \mathrm{NS})$. At higher insulin concentrations, down-regulation of insulin receptor binding was not a consistent finding either (data not shown).

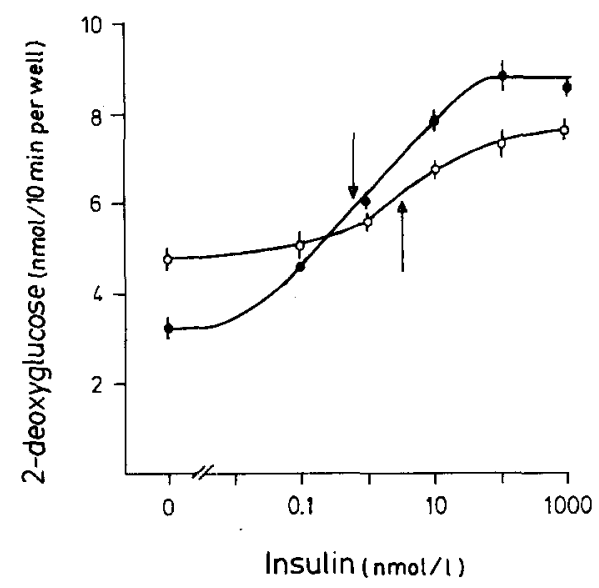

Fig. 1. Dose-response relationship of the insulin-sensitive 2-deoxyglucose uptake. Control cells $(O)$ and cells cultured in the presence of insulin $(1000 \mathrm{nmol} / \mathrm{l})$ for $24 \mathrm{~h}(\mathbf{O})$ were subjected to the deactivation procedure and uptake of 2-deoxyglucose $(0.1 \mathrm{mmol} / \mathrm{l})$ was determined in the presence of increasing amounts of insulin. Arrows indicate the $\mathrm{ED}_{50}$ insulin concentration. Data are the mean $\pm \mathrm{SD}$ of triplicate determinations of one representative experiment 


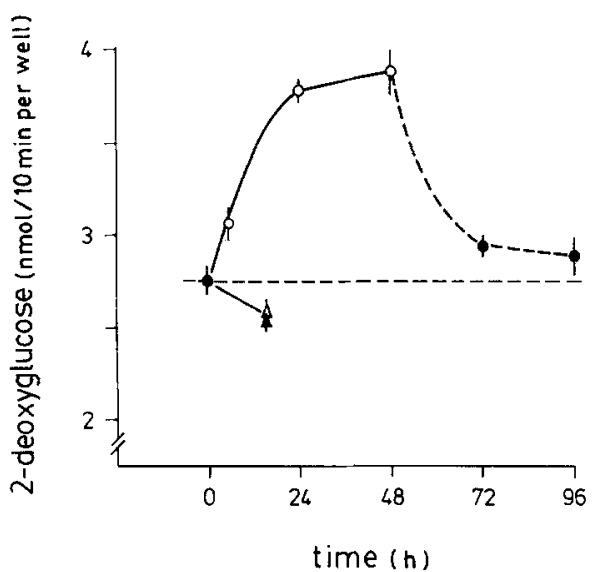

Fig. 2. Time course, reversibility and protein synthesis dependence of the long-term insulin effect. Basal 2-deoxyglucose uptake was determined after culturing fat cells in the presence of insulin $(1000 \mathrm{nmol} / 1)$ (O), in the absence of insulin following 48-h exposure to insulin (O) and in the absence $(\Delta)$ and presence $(\triangle)$ of insulin in medium containing cycloheximide $(1 \mu \mathrm{g} / \mathrm{ml})$. The dotted line represents the uptake value of control cells. Data are the mean \pm SD of triplicate determinations of one representative experiment

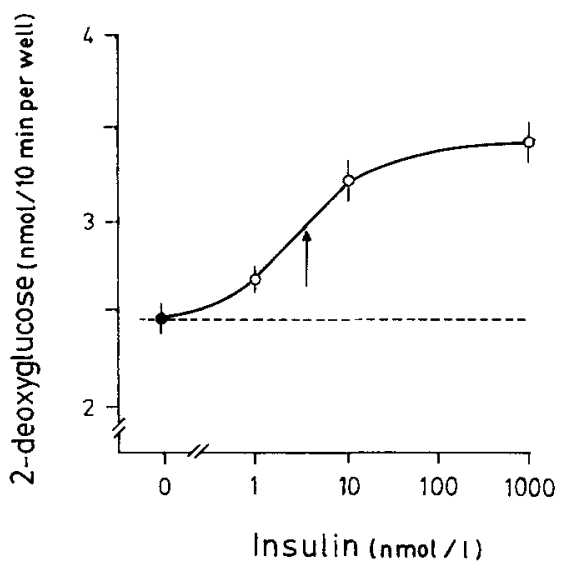

Fig. 3. Concentration dependence of the long-term insulin effect. Fat cells were cultured in the presence of various concentrations of insulin for $24 \mathrm{~h}$. After the deactivation procedure, the uptake of 2-deoxyglucose in the absence of insulin was determined. The arrow indicates the $\mathrm{ED}_{50}$ insulin concentration. The dotted line represents the uptake value of control cells. Data are the mean \pm SD of triplicate determinations of one representative experiment

Time-course experiments showed that the long-term effect of insulin was maximal within $24 \mathrm{~h}$ (Fig. 2). When cells were cultured first in the presence of insulin for $24 \mathrm{~h}$ and subsequently in the absence of the hormone, the long-term effect of insulin disappeared within $24 \mathrm{~h}$ (Fig. 2). The mediation of the long-term effect of insulin was prevented when cycloheximide $(1 \mu \mathrm{g} / \mathrm{ml})$, an inhibitor of protein synthesis, was present in the culture medium (Fig. 2). In contrast, the acute stimulatory effect of insulin was not affected by cycloheximide (data not shown), suggesting that the acute and long-term effects of insulin were mediated by different mechanisms.

Variations of the insulin concentration in the culture medium revealed that the long-term insulin effect was
Table 1. Characteristics of 2-deoxyglucose uptake into insulin-treated $(24 \mathrm{~h})$ and control cells

\begin{tabular}{lclll}
\hline & $\begin{array}{l}\text { Control } \\
\text { cells }\end{array}$ & $\begin{array}{l}\text { Insulin- } \\
\text { treated } \\
\text { celis }\end{array}$ & $p$ \\
\hline $\begin{array}{l}\text { Hexokinase activity (nmol/ } \\
\text { min per well) }\end{array}$ & $3.5 \pm 0.2$ & $4.9 \pm 0.4$ & $<0.001$ \\
$\begin{array}{l}\text { Amount of intracellular } \\
\text { 2-deoxyglucose (pmol/ }\end{array}$ & $98.0 \pm 9.0$ & $90.0 \pm 11.0$ & $\mathrm{NS}$ \\
$\begin{array}{l}10 \text { min per well) } \\
\begin{array}{l}\text { Intracellular water space } \\
\text { (ul/well) }\end{array}\end{array}$ & $3.58 \pm 0.12$ & $3.49 \pm 0.15$ & $\mathrm{NS}$ \\
$\begin{array}{l}\text { Intracellular 2-deoxyglucose } \\
\text { concentration ( } \mu \text { mol/1) }\end{array}$ & $27.5 \pm 1.4$ & $26.0 \pm 1.8$ & $\mathrm{NS}$ \\
$\begin{array}{l}\mathrm{K}_{\mathrm{m}} \text { of 2-deoxyglucose up- } \\
\text { take (mmol/l) }\end{array}$ & $2.1 \pm 0.2$ & $2.3 \pm 0.2$ & $\mathrm{NS}$ \\
$\begin{array}{l}\mathrm{V}_{\text {max }} \text { of 2-deoxyglucose up- } \\
\text { take (nmol/min per well) }\end{array}$ & $4.0 \pm 0.1$ & $6.1 \pm 0.3$ & $<0.005$ \\
\hline
\end{tabular}

Data are expressed as the mean $\pm \mathrm{SD}$ of four experiments

maximal after exposing cells to $1000 \mathrm{nmol} / 1$ insulin (initial concentration) (Fig. 3). The $\mathrm{ED}_{50}$ was $4.5 \pm 0.36$ nmol $/ 1$ (mean $\pm \mathrm{SD}, n=3$ ), slightly in excess of the $\mathrm{ED}_{50}$ of the acute stimulatory effect of insulin in the insulin-pre-treated $(24 \mathrm{~h})$ cells $(3.10 \pm 0.26 \mathrm{nmol} / 1)$, and approximately eight times the $\mathrm{ED}_{50}$ of the acute insulin effect in the control cells $(0.56 \pm 0.15 \mathrm{nmol} / \mathrm{l})$. These data, however, should be interpreted with caution, since estimation of the insulin degradation by the trichlorocetic acid precipitation method [25] indicated that the cells degraded $40 \%$ of $1 \mathrm{nmol} / 1^{125} \mathrm{I}$-insulin and $4 \%$ of $1000 \mathrm{nmol} / 1^{125} \mathrm{I}$-insulin during the incubation period $\left(24 \mathrm{~h}\right.$ at $\left.37^{\circ} \mathrm{C}\right)$.

To delineate further the long-term effect of insulin, the 2-deoxyglucose uptake process, which involves transport of hexose across the membrane and formation of 2-deoxyglucose 6-phosphate, was studied in more detail. Long-term exposure ( $24 \mathrm{~h}$ ) of the cells to insulin $(1000 \mathrm{nmol} / 1)$ increased the hexokinase activity of the cells up to $30 \%$ (Table 1 ). This increase was a specific long-term effect, since short-term exposure of the cells $(30 \mathrm{~min})$ to insulin did not affect the enzyme activity (control cells) (Table 1). The increase in hexokinase activity might explain the observed increase in 2-deoxyglucose uptake, if phosphorylation and not transport is the rate-limiting step in the 2 -deoxyglucose uptake process. However, chromatography of the labelled compounds inside the cells (during the uptake) revealed that the intracellular concentration of non-phosphorylated 2-deoxyglucose, as calculated from data on the amounts of non-phosphorylated 2-deoxyglucose inside the cells and the intracellular water space, was never more than $20-30 \%$ of the extracellular concentration $(100 \mu \mathrm{mol} / 1 ; p<0.001$; Table 1$)$. The same results were obtained when $100 \mu \mathrm{mol} / 1$ cytochalasin $B$ was used to stop the 2-deoxyglucose uptake (data not shown), indi- 


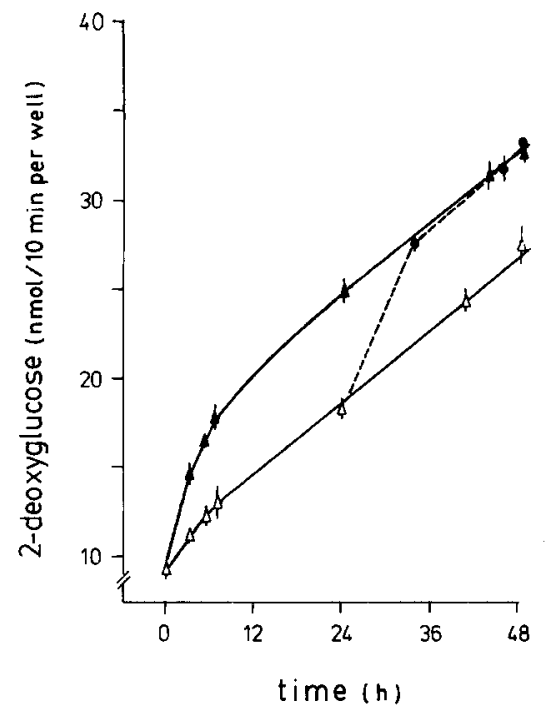

Fig.4. Long-term insulin effect on glucose-deprived cells. Fat cells were cultured in the absence of glucose for $48 \mathrm{~h}$ in the absence $(\Delta)$ and presence of insulin $(1000 \mathrm{nmol} / 1)$. Insulin was added at the start (A) and at $24 \mathrm{~h}(\boldsymbol{)})$ after the initiation of the glucose deprivation. At the time points indicated 2-deoxyglucose uptake $(0.1 \mathrm{mmol} / 1)$ was assayed in the presence of insulin $(1000 \mathrm{nmol} / \mathrm{l})$. Data are the mean of triplicate determinations of one representative experiment

cating that efflux of non-phosphorylated 2-deoxyglucose was negligible. The absence of substantial accumulation of non-phosphorylated 2-deoxyglucose inside the cells suggests that transport rather than phosphorylation was rate-limiting in the uptake process and, therefore, that the long-term effect of insulin on the 2-deoxyglucose uptake is mediated by an alteration in activity of the hexose transport system.

Theoretically, an increase in 2-deoxyglucose transport can be attained by an increase in the number and/ or activity of the hexose transporters and by an increase in the affinity of the hexose transporters for the hexose. Lineweaver-Burk analysis of a concentration curve of 2-deoxyglucose uptake $(0.1-5 \mathrm{mmol} / 1$ for $2 \mathrm{~min})$ by insulin-treated $(24 \mathrm{~h})$ and control cells revealed that the long-term insulin effect was primarily due to an increase in the apparent $V_{\max }$ of the 2-deoxyglucose uptake process (Table 1), i.e. to an increase in the number and/or activity of the hexose transporters. The alteration in hexose transport kinetics was further explored by determining the long-term insulin effect in cells cultured in the absence of glucose. Glucose deprivation has been shown to increase the 2-deoxyglucose uptake by decreasing the rate of inactivation or degradation ('turnover') of hexose transporters (personal observations). As shown in Figure 4, the long-term effect of insulin is still present in cells cultured in the absence of glucose $(n=4, p<0.001)$. This observation indicates that glucose is not essential for mediation of the longterm insulin effect and, furthermore, that the insulin-induced increase in hexose transport activity is most likely due to an increase in transporter synthesis.

\section{Discussion}

In the present study, we tried to delineate the role of insulin in the long-term regulation of hexose uptake in cultured $3 \mathrm{~T} 3-\mathrm{L}_{1}$ fat cells. The data demonstrate that in cultured fat cells insulin is a long-term regulator of 2-deoxyglucose uptake. Prolonged exposure to insulin increased the basal 2-deoxyglucose uptake and decreased the acute stimulatory effect of insulin on 2-deoxyglucose uptake. The effect was time-, concentration-, and protein-synthesis dependent, and reversible. It was not due to insufficient removal of insulin from the cells, since the long-term effect was inhibited by cycloheximide, in contrast to the acute insulin effect. Furthermore, the effect was not due to non-specific mechanisms, such as a mitogenic effect or an insulin-induced enhancement of the differentiation of the cultured cells, as shown by the reversibility of the effect, the constant cell number and the observation that upon differentiation the basal hexose uptake tends to decrease instead of increase [26]. In the same cell line, Karlsson et al. [27] have noticed similar alterations in the insulin-stimulated hexose uptake after $20 \mathrm{~h}$ of exposure to insulin. Our data and Karlsson's data contrast with the results of Rosen et al. [28], who have reported an insulin-induced increase in basal and insulin-stimulated hexose uptake. The reason for this discrepancy is not clear, but could be due to their use of cells at an early stage of differentiation.

The long-term effect of insulin concerns two different aspects of the insulin-sensitive hexose uptake: the (acute) stimulatory effect on the hexose uptake and the basal hexose uptake. The effect on the 'acute' insulin response cannot be explained by an alteration in insulin binding, since down-regulation of insulin receptor binding was not a consistent finding. Whether 3T3 adipocytes have the ability to down-regulate is still controversial [20,27, 29-32], but it might depend on the stage of differentiation of the cells. At an early stage of differentiation insulin has been shown to enhance the number of insulin receptors [20,27, 29, 31]. The absence of substantial alterations in insulin binding implies that the loss in insulin response is due to post-receptor alterations. There is a close resemblance between the longterm insulin effect and the desensitization process observed after incubating fat cells with serum of insulinresistant patients [33] and anti-insulin receptor antibodies [34]. These observations suggest that the mediation of these processes have steps in common, but further studies are required to elucidate the mechanisms responsible for decreased insulin effectiveness.

The long-term effect of insulin on basal 2-deoxyglucose uptake was found to be due to an increase in the apparent $\mathrm{V}_{\max }$ of the 2-deoxyglucose uptake, a process which involves transport and phosphorylation of the hexose. In rat adipose cells, it has been argued that 2-deoxyglucose uptake reflects its transport only, when low concentrations are used and uptake is measured 
over short time intervals. At higher 2-deoxyglucose concentrations and with prolongation of the uptake period, the phosphorylation reaction would become rate-limiting [35]. In the cultured fat cells, prolonged insulin treatment increased the hexokinase activity of the cells. Since during the uptake period the intracellular concentration of the hexose of non-phosphorylated 2-deoxyglucose was far below the extracellular concentration, even when cytochalasin B was present to prevent efflux of non-phosphorylated 2-deoxyglucose, in the cultured fat cells 2-deoxyglucose transport or perhaps transportassociated phosphorylation, but certainly not intracellular phosphorylation appears to be the rate-limiting step in the uptake process. Consequently, the insulin-induced increase in basal 2-deoxyglucose uptake can be attributed to an increase in the number or activity of hexose transporters rather than to an increase in hexokinase activity. The discrepancy between our results and those of Foley et al. [35] regarding the amount of nonphosphorylated 2-deoxyglucose inside the fat cells is unclear, but it may be related to differences in the extraction procedure, or to their use of phloretin to stop the hexose uptake process. Phloretin has been shown to have drastic effects on fat cell metabolism [36], including rapid dephosphorylation of 2-deoxyglucose 6-phosphate [23].

A protein synthesis-dependent increase in the number or activity of hexose transporters can be attained by an increase in de novo synthesis of hexose transporters and by a decrease in their degradation ('turnover'). A protein-synthesis dependent activation or inactivation of hexose transporters has never been described, but nevertheless it cannot be ruled out completely. The finding that the long-term effect of insulin was present even when glucose was omitted from the culture medium, which has been shown to slacken the 'turnover' of transporters (unpublished observations), suggests that the insulin-induced increase in basal 2-deoxyglucose transport is due to an increase in 'synthesis' of transporters rather than to an inhibition of the 'turnover'. The glucose deprivation experiments further indicate that glucose is not essential for mediation of the long-term insulin effect.

The observation that insulin acts as a long-term regulator of hexose uptake in vitro fits well with observations in vivo: high concentrations of insulin are accompanied by a high basal hexose uptake, whereas low insulin concentrations are parallelled by a low basal hexose uptake [1-11]. Recently, Ciaraldi et al. [37] reported the existence of insulin resistance and a low basal hexose uptake in fat cells of patients with Type 2 (non-insulin-dependent) diabetes. Considering our data, it is possible that in Type 2 diabetic patients the long-term insulin effect of stimulating the 'synthesis' of transporters is decreased, resulting in a low basal hexose uptake. This idea is strengthened by the finding of Scarlett et al. [38] that prolonged intensive insulin therapy in Type 2 diabetes significantly reverses the low basal hexose transport activity. Obviously, more insight into the regulation of hexose transporter kinetics is required to make more definitive statements on the role of the long-term effects of insulin in glucose homeostasis.

Acknowledgements. We thank W. Dijkstra-van der Star for excellent technical assistance with the cell culture, and C. van den Haak for typing the manuscript. This work was supported by the Foundation of Medical Research FUNGO, which is subsidized by the Netherlands Organization for the Advancement of Pure Research (ZWO).

\section{References}

1. DeFronzo RA, Hendler R, Simonson D (1982) Insulin resistance is a prominent factor of insulin-dependent diabetes. Diabetes 31 : 795-801

2. Pedersen O, Hjøllund E (1982) Insulin receptor binding to fat and blood cells and insulin action in fat cells from insulin dependent diabetics. Diabetes 31: 706-715

3. Wieringa Tj, Krans HMJ (1978) Reduced glucose transport and increased binding of insulin in adipocytes from diabetic and fasted rats. Biochim Biophys Acta 538: 563-570

4. Radder JK, Wieringa T $j$, Bos MP, Krans HMJ (1984) The effect of normalization of blood glucose levels in streptozotocin-diabetic rats with continuous intravenous insulin infusion on insulin binding and glucose transport of isolated adipocytes. In: Shafrir E, Renold AE (eds) Lessons from animal diabetes. John Libbey, London, 622-626

5. Kasuga M, Akanuma Y, Iwamoto Y, Kosaka K (1978) Insulin binding and glucose metabolism in adipocytes of streptozotocin diabetic rats. Am J Physiol 235: E175-E183

6. Kobayashi M, Olefsky JM (1979) Effects of streptozotocin induced diabetes on insulin binding, glucose transport and intracellular glucose metabolism in isolated rat adipocytes. Diabetes 28: $87-95$

7. Olefsky JM (1976) Effects of fasting on insulin binding, glucose transport and glucose oxidation in isolated rat adipocytes. J Clin Invest 58: $1450-1460$

8. Oka Y, Akanuma Y, Kasuga M, Kosaka K (1980) Effect of a high glucose diet on insulin binding and insulin action in rat adipocytes. Diabetologia 19:468-474

9. Saekow M, Olefsky JM (1980) Effect of a high carbohydrate diet on adipocyte glucose metabolism in spontaneously obese rats and insulin deficient diabetic rats. Endocrinology 107: 2004-2010

10. Ip C, Tepperman HM, deWitt J, Tepperman J (1977) The effect of diet fat on rat adipocyte glucose transport. Horm Metab Res 9: $218-222$

11. Kobayashi M, Olefsky JM (1978) Long-term regulation of adipocyte glucose transport capacity by circulating insulin in rats. J Clin Invest 62: 73-81

12. Livingston JN, Purvis BJ, Lockwood DH (1978) Insulin-induced changes in insulin binding and insulin sensitivity of adipocytes. Metabolism 27: 2009-2014

13. Livingston JN, Purvis BJ, Lockwood DH (1978) Insulin-dependent regulation of insulin sensitivity of adipocytes. Nature 273: 394-396

14. Marshall S, Olefsky JM (1980) Effects of insulin incubation on insulin binding, glucose transport and insulin degradation by isolated rat adipocytes. J Clin Invest 66: 763-772

15. Vega FV, Kono T (1979) Sugar transport in fat cells: effect of mechanical agitation, cell-bound insulin and temperature. Arch Biochem Biophys 192: 120-127

16. Kikuchi K, Schwartz C, Creacy S, Larner J (1981) Independent control of selected insulin sensitive cell membrane and intracellular functions - the linkage of cell membrane and intracellular events controlled by insulin. Mol Cell Biochem 37: 125-130

17. El-Allaway RMM, Gliemann J (1972) Trypsin treatment of adipo- 
cytes: effect on sensitivity to insulin. Biochim Biophys Acta 271: 97-109

18. Green $\mathrm{H}$, Kehinde O (1974) Sublines of mouse $3 T 3$ cells that accumulate lipid. Cell 1: 113-116

19. Green H (1979) Adipose conversion: a program of differentiation. In: Ailhaud $G$ (ed) Obesity, cellular and molecular aspects. Inserm, Nice 87: $15-24$

20. Rubin CS, Hirsch A, Fung C, Rosen OM (1978) Development of hormone receptors and hormonal responsiveness in vitro. $\mathrm{J}$ Biol Chem 253: 7570-7578

21. Reed BC, Lane MD (1980) Insulin receptor synthesis and turnover in differentiating 3T3- $\mathrm{L}_{1}$ preadipocytes. Proc Natl Acad Sci USA 77: $285-289$

22. Sedmak JJ, Grossberg SE (1977) A rapid, sensitive and versatile assay for protein using Coomassie Brilliant Blue G 250. Anal Biochem 79:544-553

23. Wieringa Tj, van Putten JPM, Krans HMJ (1981) Rapid phloretin induced dephosphorylation of 2-deoxyglucose 6-phosphate in rat adipocytes. Biochem Biophys Res Commun 103: 841-847

24. Gliemann J, Osterlind K, Vinten J, Gammeltoft S (1972) A procedure for measurement of distribution spaces in isolated fat cells. Biochim Biophys Acta 286: 1-9

25. Freychet P, Kahn CR, Roth J, Neville DM Jr (1972) Insulin interactions with liver plasma membrane. J Biol Chem 247: 3953-3961

26. Resh MD (1982) Development of insulin responsiveness of the glucose transporter and the $\left(\mathrm{Na}^{+}, \mathrm{K}^{+}\right)$-adenosine triphosphatase during in vitro adipocyte differentiation. J Biol Chem 257: 6978-6986

27. Karlsson FA, Grunfeld C, Kahn CR, Roth J (1979) Regulation of insulin receptors and insulin responsiveness in $3 \mathrm{~T} 3-\mathrm{L}_{1}$ fatty fibroblasts. Endocrinology 104: 1383-1392

28. Rosen OM, Smith CJ, Fung C, Rubin CS (1979) Development of hormone receptors and hormone responsiveness in vitro. $\mathrm{J}$ Biol Chem 253: 7579-7583

29. Reed BC, Ronnett GV, Clements PR, Lane MD (1981) Regulation of insulin receptor metabolism. J Biol Chem 256: 3917-3925

30. Ronnett GV, Knutson VP, Lane MD (1982) Insulin-induced down-regulation in $3 \mathrm{~T} 3-\mathrm{L}_{1}$ adipocytes. $\mathrm{J}$ Biol Chem 257: $4285-4291$

31. Ronnett GV, Tennekoon G, Knutson VP, Lane MD (1983) Kinetics of insulin receptor transit and removal from the plasma membrane. J Biol Chem 258: 283-290

32. Chang T, Polakis SE (1978) Differentiation of $3 T_{3}-\mathrm{L}_{1}$ fibroblasts to adipocytes. J Biol Chem 253: 4693-4696

33. Kahn CR, Baird K, Flier JS, Jarrett DB (1977) Effects of autoantibodies to the insulin receptor on isolated adipocytes. J Clin Invest 60: 1094-1106

34. Karlsson FA, van Obberghen E, Grunfeld C, Kahn CR (1979) Desensitization of the insulin receptor at an early post receptor step by prolonged exposure to anti-receptor antibody. Proc Natl Acad Sci USA 76: 809-813

35. Foley JE, Foley R, Gliemann J (1980) Rate-limiting steps of 2-deoxyglucose uptake in rat adipocytes. Biochim Biophys Acta 599: 689-698

36. de Jonge PC, Wieringa Tj, van Putten JPM, Krans HMJ, van Dam K (1983) Phloretin - an uncoupler and inhibitor of mitochondrial oxidative phosphorylation. Biochim Biophys Acta 722: 219-225

37. Ciaraldi TP, Kolterman OG, Scarlett JA, Kao M, Olefsky JM (1982) Role of glucose transport in postreceptor defect in non-insulin-dependent diabetes mellitus. Diabetes 31: 1016-1022

38. Scarlett JA, Kolterman OG, Ciaraldi TP, Kao M, Olefsky JM (1983) Insulin treatment reverses the postreceptor defect in adipocyte 3-O-methylglucose transport in type II diabetes mellitus. J Clin Endocrinol Metab 56: 1195-1201

Received: 30 January 1984

and in revised form: 27 August 1984

Professor Dr. H.M.J. Krans

Department of Endocrinology and Metabolic Diseases

University Hospital, Building 30

NL-2333 AA Leiden

The Netherlands 